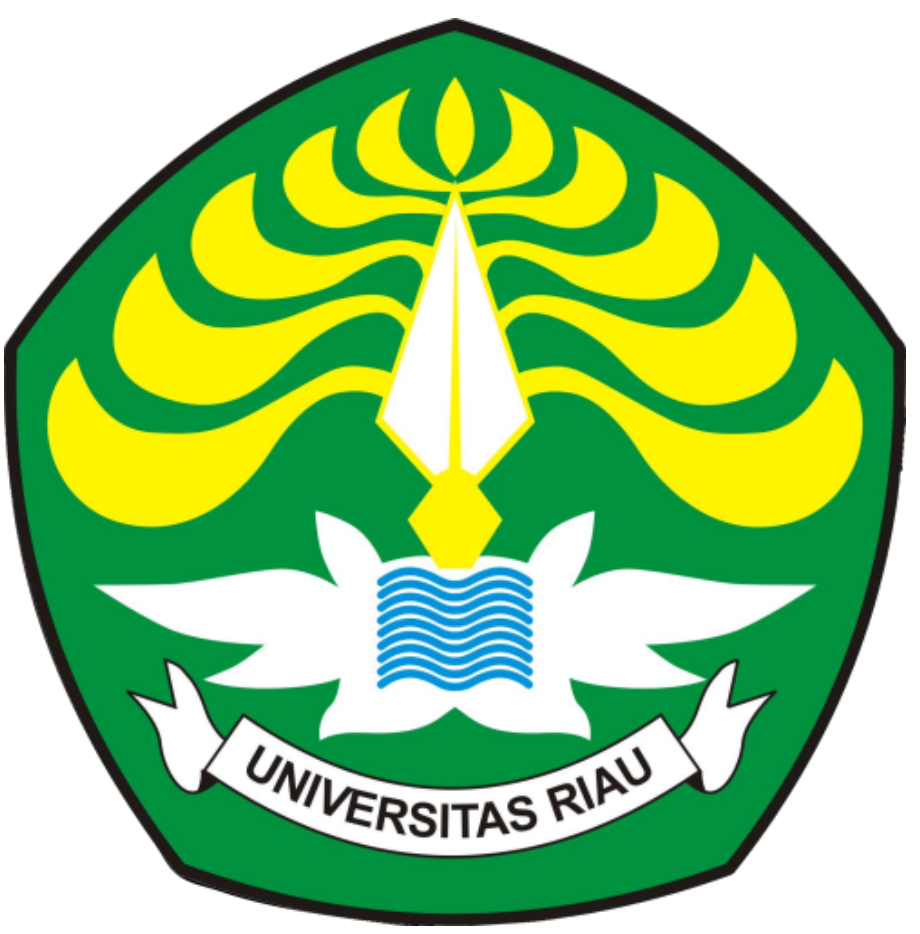

DISUSUN OLEH:

Ayu Sutrah

FAKULTAS KEGURUAN DAN ILMU PENDIDIKAN

PROGRAM STUDI PENDIDIKAN BAHASA DAN SATRA INDONESIA UNIVERSITAS RIAU 


\section{Peran Orang Tua dalam Pembelajaran Anak di Masa Pandemi}

\section{Latar Belakang}

Saat ini bumi sedang sedang ditimpa musibah besar, yaitu wabah atau virus yang biasa dikenal dengan Covid-19 atau virus korona. Virus ini menyerang manusia di seluruh dunia, sehingga menyebabkan negara-negara di dunia sangat waspada, dan menetapkan untuk melakukan kegiatan dari rumah saja, serta harus social distancing untuk menjaga agar memperlambat penyebaran virus korona tersebut. Menurut WHO (2019), Corona virus merupakan keluarga besar virus yang menyebabkan penyakit pada manusia dan hewan. Pada manusia biasanya menyebabkan penyakit infeksi saluran pernapasan, mulai flu biasa hingga penyakit yang serius seperti Middle East Respiratory Syndrome (MERS) dan Sindrom Pernafasan Akut Berat/ Severe Acute Respiratory Syndrome (SARS) (Nahdi et al., 2020; Wax \& Christian, 2020). Corona virus merupakan jenis baru yang ditemukan pada manusia sejak kejadian luar biasa muncul di Wuhan, Cina, pada Desember 2019, kemudian diberi nama Severe Acute Respiratory Syndrome Coronavirus 2 (SARS-COV2), dan menyebabkan penyakit Coronavirus Disease-2019(COVID-19).

Pandemi Covid-19 membuat beberapa sarana umum mati atau ditutup sementara, termasuk sekolah yang membuat kegiatan belajar mengajar dialihkan menjadi kegiatan pembelajaran jarak jauh demi keamanan dan kesehatan. Hal ini tentunya berdampak untuk orang tua, dimana orang tua harus memberikan pembelajaran pada anaknya di rumah.

Sun, Tang, dan Zou (2020) menyebutkan bahwa dampak covid ini membuat kegiatan belajar dilakukan dengan jarak jauh bagi semua elemen khususnya peserta didik dan pendidik, hingga orang tua. Tentu hal ini menuai pro dan kontra, banyak orang tua yang mengungkapkan bahwa mereka merasa keberatan ketika anak belajar di rumah, karena di rumah anak merasa bukan waktunya belajar namun mereka cenderung menyukai bermain saat di rumah, walaupun di situasi pandemi seperti ini. Namun, tidak sedikit juga orang tua yang setuju dengan diberlakukannya sekolah daring ini, karena tentu saja keamanan dan kesehatan para siswa terjamin karena tidak bertemu dengan orang banyak setiap harinya, dimana resiko tertular virus sedikit. Maka disini akan terlihat bagaimana pola asuh 
orang tua saat belajar di rumah.

\section{Peran Orang Tua}

Menurut Khairani (2019: 20) peran merupakan suatu kompleks pengharapan manusia terhadap caranya individu harus bersikap dan berbuat dalam situasi tertentu bedasarkan status dan fungsi sosialnya. Kata peran dalam kamus Oxford Dictionary diartikan dengan Actor's Part, One's TASK Of Function yang berarti aktor, tugas seseorang atau fungsi.

Orang tua memiliki andil yang sangat besar dalam kemampuan anak dalam lingkup pendidikan, jika orang tua kurang dalam pendidikan anaknya, maka dapat menyebabkan anak kurang atau bahkan tidak berhasil dalam belajarnya. Sebaliknya, jika orang tua yang selalu memberi perhatian pada anaknya, terutama perhatian pada kegiatan belajar mereka dirumah, akan membuat anak lebih giat dan lebih bersemangat dalam belajar karena ia tahu bahwa bukan dirinya sendiri saja yang berkeinginan untuk maju, akan tetapi orang tuanya juga memiliki keinginan yang sama. Sehingga hasil belajar atau prestasi belajar yang diraih oleh siswa menjadi lebih baik.

Terdapat beberapa faktor yang mempengaruhi pola asuh orang tua menurut Hurlock (1999), yaitu karakteristik orang tua yang berbeda-beda. Kepribadian orang tua setiap orang berbeda dalam tingkat energi, kesabaran, intelegensi, sikap dan kematangannya. Karakteristik tersebut akan mempengaruhi kemampuan orang tua untuk memenuhi tuntutan peran sebagai orang tua dan bagaimana tingkat sensitivitas orang tua terhadap kebutuhan anak-anaknya. Bila orang tua merasa bahwa orang tua mereka dahulu berhasil menerapkan pola asuhnya pada anak dengan baik, maka mereka akan menggunakan teknik serupa dalam mengasuh anak bila mereka merasa pola asuh yang digunakan orang tua mereka tidak tepat, maka orang tua akan beralih ke teknik pola asuh yang lain yang tentunya diharapkan akan lebih baik.

Peran orang tua juga sangat diperlukan untuk memberikan edukasi kepada anak-anaknya yang masih belum bisa memahami tentang pandemi yang sedang mewabah untuk tetap berdiam diri dirumah agar tidak tertular dan menularkan wabah pandemi ini. Peran orang tua dalam situasi pandemi Covid-19 ini memiliki 
kedudukan yang fundamental. Sejak virus Corona menyebar di Indonesia pada awal Maret, pemerintah segera melakukan tindakan tegas untuk mencegah penyebaran yang lebih luas. Karna pada kasus ini, penyakit yang disebabkan oleh virus Corona dapat menyebar sangat cepat dan telah banyak memakan korban jiwa di berbagai negara, sehingga pemerintah melakukan berbagai upaya untuk mencegah penyebaran yang sangat luas, dimana salah satunya adalah dengan menerapkan pembelajaran jarak jauh, baik dari tingkat dasar hingga tingkat perguruan tinggi. Dalam pelaksanaannya guru dan pendidik lainnya mencoba untuk memanfaatkan ilmu teknologi untuk menyikapi masalah pembelajaran jarak jauh dengan cara memberikan materi serta tugas pelajaran melalui online. Namun hal tersebut tidaklah selalu berjalan dengan baik, terdapat banyak kendala dalam pelaksanaannya, seperti kuota dan sinyal yang tak memadai, bahkan beberapa pelajar tidak mempunyai penunjang alat elektronik yang baik, dan hal ini mengakibatkan materi pembelajaran tidak tersampaikan dengan baik, sehingga banyak pelajar yang kurang mengerti dan merasa tidak terbimbing dengan baik dalam memahami pelajaran menggunakan pembelajaran jarak jauh ini.

Oleh karena itu sangat dibutuhkan peran orang tua untuk mengganti sosok guru di rumah dalam membimbing anaknya selama proses kegiatan pembelajaran jarak jauh. Menurut Winingsih (2020) terdapat empat peran orang tua selama Pembelajaran Jarak Jauh (PJJ) yaitu: 1. Orang tua memiliki peran sebagai guru di rumah, yang di mana orang tua dapat membimbing anaknya dalam belajar secara jarak jauh dari rumah. 2. Orang tua sebagai fasilitator, yaitu orang tua sebagai sarana dan pra-sarana bagi anaknya dalam melaksanakan pembelajaran jarak jauh. 3. Orang tua sebagai motivator, yaitu orang tua dapat memberikan semangat serta dukungan kepada anaknya dalam melaksanakan pembelajaran, sehingga anak memiliki semangat untuk belajar, serta memperoleh prestasi yang baik. 4 . Orang tua sebagai pengaruh atau director.

Bedasarkan hasil penjelasan diatas dapat diketahui bahwa orang tua merasa pembelajaran di rumah menjadi kurang efektif diterapkan. Hal ini dikarenakan pembelajaran di rumah yang cenderung diberi tugas dan kurangnya penjelasan terkait materi tugas yang diberikan. Hal ini tidak sejalan dengan pendapat Sekretaris Jenderal Federasi Serikat Guru Indonesia, Heru Purnomo, bahwa dalam pembelajaran jarak jauh sampai saat ini, efektif dalam mengerjakan 
penugasan. Tapi, dalam pembelajaran untuk memahami konsep, kemudian mengembangkan konsep itu sampai refleksi, tidak berjalan dengan sebaik itu ((Nahdi et al., 2021; Simha et al., 2020)).

Adapun strategi yang dapat dilakukan untuk mendampingi anak dalam belajar di rumah yaitu,

1. Memahami Gaya Belajar Anak, Setiap anak memiliki gaya belajar yang berbeda-beda. Orang tua diharapkan mengenal dan memahami cara belajar anak, agar memudahkan dalam mendampingi anak. Mulai dari cara visual, auditori, maupun kinestetik.

2. Menyiapkan Lingkungan Belajar Anak . Anak dapat belajar dari lingkungan sekitarnya mulai dari keluarga, sekolah, dan masyarakat. Hal ini dapat dilakukan orang tua dalam mendampingi anak belajar di rumah dengan cara mengajarkan anak kemandirian; mengajarkan anak tata karma; dan mendampingi anak belajar sesuai dengan kebutuhan anak (Kementerian Pendidikan dan Kebudayaan, 2016)\

\section{KESIMPULAN}

Pandemi Covid-19 membuat beberapa sarana umum mati atau ditutup sementara, termasuk sekolah yang membuat kegiatan belajar mengajar dialihkan menjadi kegiatan pembelajaran jarak jauh demi keamanan dan kesehatan. Dalam hal ini peran orang tua jelas bertambah menjadi dua yaitu sebagai orang tua dan sosok pengganti guru di rumah dalam membimbing anaknya selama proses kegiatan pembelajaran jarak jauh. Hal ini menimbulkan banyak rintangan-rintangan yang didapatkan orang tua dalam membantu anaknya saat pembelajaran daring ini, seperti sulitnya membagi waktu, kurang jelasnya materi yang disampaikan, keterbatasan pendidikan orang tua dalam membantu pembelajaran anak, dan kurang fokusnya anak saat pembelajaran di rumah. Para orangtua berpendapat bahwa PJJ yang efektif yaitu dengan cara guru memberikan sebuah video atau melakukan pembelajaran tatap maya seperti menggunakan aplikasi zoom, karena para anak tidak mudah mengerti apabila hanya diberikan sebuah materi tanpa diterangkan oleh gurunya, solusi yang dapat diambil orang tua dalam permasalahan ini yaitu orang tua dapat mengambil strategi untuk mendampingi anak dalam belajar di rumah yaitu, memahami gaya belajar anakseperti, menggunakan lebih banyak gambar daripada kata-kata, menggunakan alat peraga, 
penataan ruang belajar yang nyaman dan dekoratif hasil karya anak, belajar melalui film, dan lain

lain.

Pada akhirnya dapat dilihat bahwa bukan berarti pembelajaran di sekolah tidak lebih efektif dibandingkan dengan pembelajaran jarak jauh, pembelajaran jarak jauh ini dinilai tidak lebih menguntungkan untuk siswa karena siswa hanya diberikan tugas tanpa dijelaskan terlebih dahulu, banyak orang tua yang setuju apabila tahun ini pemerintah mulai memperbolehkan sekolah tatap muka dikarenakan anak akan mampu mendapat informasi dari materi yang diberikan dengan lebih jelas, terperinci dan aktif, serta anak juga dapat bersosialisasi dengan baik. Namun, tetap dengan mematuhi protokol kesehatan dan jika kondisi yang mulai membaik. Tetapi tidak sedikit orang tua yang tidak setuju dan tidak mengizinkan anaknya bersekolah tatap muka dikarenakan kondisi yang belum stabil dan lebih mengutamakan kesehatan anak karena anak merupakan aset bangsa yang harus tubuh dengan sehat dan berkarya.

\section{Referensi}

Zulhafizh, S Permatasari (2020). Developing Quality Of Learning In The Pandemic Covid- 19 Through Creative And Critical Thinking Attitudes. Jurnal PAJAR (Pendidikan dan Pengajaran) ID Patent EC00,202,038,348

Ahsani, E. (2020). Strategi Orang Tua dalam Mengajar dan Mendidik Anak dalam Pembelajaran At The Home Masa Pandemi Covid-19. Athfal, 39-44. Diambil 03 Januari2021,dari

:https://ejournal.stainupwr.ac.id/index.php/Al_Athfal/article/view/ 180/105

Anugrahana, Andri. (2020). Hambatan, Solusi dan Harapan : Pembelajaran Daring Selama Masa Pandemi Covid-19 Oleh Guru Sekolah Dasar. Scholaria, 282-289. Diambil 12 Januari 2021, dari https://ejournal.uksw.edu/scholaria/article/view/4033/1527

Asmun. (2020). Problematika Pembelajaran Daring di Masa Pandemi Covid-19 dan Solusi Pemecahannya. Paedagogy, 281-288. Diambil 11 Januari 2021, dari : https://ojs.ikipmataram.ac.id/index.php/pedagogy/article/view/2941

Aziza, F, N., \& Yunus, M. (2020). PERAN ORANG TUA DALAM MEMBIMBING ANAK PADA MASA STUDY FROM HOME SELAMA PANDEMI COVID 19. UrbanGreen Proceeding, 112-114. Diambil 12 Januari 2021

Cahyati, N., \& Kusumah, R. (2020). Peran Orang Tua Dalam Menerapkan

Pembelajaran Di Rumah Saat Pandemi Covid 19. Golden Age, 5-7. Diambil 12 Januari 2021, dari :

http://ejournal.hamzanwadi.ac.id/index.php/jga/article/view/2203

Khalimah, S. N. (2020, November 9). PERAN ORANG TUA DALAM

PEMBELAJARAN

SEMARANG TAHUN
DARING DI MI DARUL ULUM PEDURUNGAN KOTA

PELAJARAN 2020/2021. Retrieved Jaunary 12, 
2021, from IAIN Salatiga Online Web site:

http://erepository.perpus.iainsalatiga.ac.id/9839/

Liliwati, A. (2021). Peran Orang Tua dalam Mendukung Kegiatan Pembelajaran di Rumah pada Masa Pandemi. Jurnal Obsesi, 551-557. Diambil 12 Januari, dari : https://obsesi.or.id/index.php/obsesi/article/view/630/pdf

Radin, I. N. (2020). Peran Orang Tua Dalam Menerapkan Pembelajaran Dari Rumah

Saat Pandemi Covid 19. Cetta, 20-26. Diambil 13 Januari 2021, dari : http://jayapanguspress.penerbit.org/index.php/cetta/article/view/693

Wardanu, A., \& Ayriza, Y. (2021). Analisis Kendala Orang Tua dalam Menghadapi

Anak Belajar di Rumah Pada Masa Pandemi Covid-19. Jurnal Obsesi, 772-782.

Diambil 12Januari 2021, dari :

https://www.obsesi.or.id/index.php/obsesi/article/view/705/p

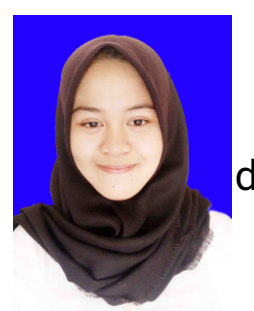

Ayu Sutrah, lahir pada tanggal 2 Januari 2000. Pada tahun akademik 2018-2019, la melanjutkan studi pada strata satu Jurusan Pendidikan Bahasa dan Seni di Program Studi dikan Bahasa dan Sastra Indonesia FKIP Universitas Riau melalui SBMPTN (Seleksi Bersama Masuk Perguruan Tinggi).

Kontak:

Hp/WA : 082283053921

Email : sutraayu7@gmail.com 